\title{
Inflammation of the choroid plexus in progressive multiple sclerosis: accumulation of granulocytes and T cells
}

\author{
Sabela Rodríguez-Lorenzo', Julia Konings' ${ }^{1}$ Susanne van der Pol ${ }^{1}$, Alwin Kamermans ${ }^{1}$, Sandra Amor ${ }^{2,3}$, \\ Jack van Horssen ${ }^{1}$, Maarten E. Witte ${ }^{1+}$, Gijs Kooij ${ }^{1+}$ and Helga E. de Vries ${ }^{1,4^{*+}}$ (D)
}

\begin{abstract}
The choroid plexus (CP) is strategically located between the peripheral blood and the cerebrospinal fluid, and is involved in the regulation of central nervous system (CNS) homeostasis. In multiple sclerosis (MS), demyelination and inflammation occur in the CNS. While experimental animal models of MS pointed to the CP as a key route for immune cell invasion of the CNS, little is known about the distribution of immune cells in the human CP during progressive phases of MS. Here, we use immunohistochemistry and confocal microscopy to explore the main immune cell populations in the CP of progressive MS patients and non-neuroinflammatory controls, in terms of abundance and location within the distinct CP compartments. We show for the first time that the CP stromal density of granulocytes and CD8+ T cells is higher in progressive MS patients compared to controls. In line with previous studies, the CP of both controls and progressive MS patients contains relatively high numbers of macrophages and dendritic cells. Moreover, we found virtually no B cells or plasma cells in the CP. MHCll+ antigenpresenting cells were often found in close proximity to T cells, suggesting constitutive CNS immune monitoring functions of the CP. Together, our data highlights the role of the CP in immune homeostasis and indicates the occurrence of mild inflammatory processes in the CP of progressive MS patients. However, our findings suggest that the CP is only marginally involved in immune cell migration into the CNS in chronic MS.
\end{abstract}

Keywords: Choroid plexus, Progressive MS, Immune cells, T cells, Granulocytes, Blood-CSF barrier

\section{Introduction}

Multiple sclerosis (MS) is a heterogeneous disease of the central nervous system (CNS) characterized by immune cell infiltration, demyelination and neurodegeneration [24]. The most common clinical form of MS is relapsing-remitting MS (RRMS), in which disease exacerbations are followed by periods of relative inactivity and recovery. The majority of RRMS patients eventually evolve into a progressive phase called secondary progressive MS (SPMS). In some patients,

\footnotetext{
* Correspondence: he.devries@amsterdamumc.nl

${ }^{\dagger}$ Maarten Witte, Gijs Kooij and Helga E. de Vries contributed equally to this work.

'Department of Molecular Cell Biology and Immunology, MS Center Amsterdam, Amsterdam Neuroscience, AmsterdamUMC, Vrije Universiteit Amsterdam, De Boelelaan, 1117 Amsterdam, The Netherlands

${ }^{4}$ Medical Biochemistry, Amsterdam Cardiovascular Sciences, Amsterdam UMC, University of Amsterdam, Meibergdreef 9, Amsterdam 1105, AZ, The Netherlands

Full list of author information is available at the end of the article
}

however, MS is progressive from the onset, referred to as primary progressive MS (PPMS). In both forms of progressive MS, clinical symptoms mostly reflect the underlying neurodegeneration. The pathological processes involved in the different phases of MS are relatively well defined. In RRMS, there is abundant immune cell invasion into the CNS through a dysfunctional and inflamed blood-brain barrier (BBB), leading to inflammatory white matter lesions. In progressive MS, neurodegeneration becomes more prominent and inflammation subsides, although lesion activity is still present [21]. While immune cell infiltration through the $\mathrm{BBB}$ is reduced in progressive MS $[9,20]$, inflammatory processes at the other CNS barriers, such as those at the choroid plexus $(\mathrm{CP})$ and meninges, may still contribute to the influx of peripheral immune cells. Indeed, it is known that chronic inflammation occurs in the meninges during progressive MS $[6,22,26]$, but less is known about the choroid plexus (CP) immune populations in progressive MS patients. 
The CPs are secretory tissues strategically located within the CNS. They are the main producers of cerebrospinal fluid (CSF) and therefore essential for regulation of CNS homeostasis. The CPs are located in each of the brain ventricles and consist of highly vascularized stroma surrounded by a tight continuous layer of epithelial cells. The vasculature of the CPs is characteristically fenestrated, resulting in a leaky interphase between the blood and the CP stroma. The tight junctions that connect the epithelial cells restrict the entry of molecules and cells into the CSF. As such, the epithelial cell layer in the $\mathrm{CP}$ is a pivotal component of the blood-CSF barrier (BCSFB). The BCSFB allows for a tightly regulated bidirectional immunosurveillance system in which immune cells can traffic through the CP into the CNS, but also vice versa [28]. Thus, the CPs, together with the $\mathrm{BBB}$ and the meninges, act as regulatory barriers for immune cells between the periphery and the CNS $[4,28]$.

Immune cells populate the CP under normal conditions, but a detailed overview of immune cell subsets that reside in the $\mathrm{CP}$ is currently lacking. The abundance of $\mathrm{MHCII}+$ cells in the $\mathrm{CP}$ [32] suggests that the $\mathrm{CP}$ may be involved in CSF monitoring and antigen presentation [28]. Upon stimulation, immune cells located at the CP can secrete cytokines or infiltrate into the CNS [17]. Accordingly, there is increasing evidence for the involvement of the $\mathrm{CP}$ immune component in MS. In the MS mouse model experimental autoimmune encephalomyelitis (EAE), the CP is an important early entry point for immune cells into the CNS [23]. In MS patients, the CSF contains higher numbers of immune cells relative to the CSF in controls $[5,10]$, which also suggests an increased traversal of immune cells across the BCSFB. In progressive MS immune activation of the $\mathrm{CP}$ in a small cohort of SPMS patients has been reported previously [32]. Together, studies suggest that the CP may act as a hub for the regulation of CNS immune homeostasis in MS pathology. On this basis, we here made a detailed assessment of human CP immune cell subsets and their localization within the CP compartments to better understand their role in MS pathogenesis.

We quantitatively and spatially characterized the CP immune cell distribution in progressive MS patients and non-neuroinflammatory controls. We show that granulocytes and $\mathrm{T}$ cells, particularly CD8+ T cells, are more abundant in the CP stroma of progressive MS patients compared to controls, but not in the CP epithelium. Moreover, we demonstrate that $\mathrm{MHCII}+$ myeloid cells densely populate the $\mathrm{CP}$ of both progressive MS and control cases. Some of these cells appeared to be in close contact with $\mathrm{T}$ lymphocytes in the stroma regardless of the disease status, suggesting that antigen presentation is a constitutive process of the CP. Remarkably, B cells and plasma cells were virtually absent in the $\mathrm{CP}$ of both progressive MS and controls. Together, this paper highlights the importance of the $\mathrm{CP}$ in CNS immune homeostasis, and provides evidence for the involvement of $\mathrm{T}$ cells and granulocytes in the $\mathrm{CP}$ in the chronic progressive phases of MS.

\section{Materials and Methods \\ Human choroid plexus tissue}

Formalin fixed, paraffin embedded CP tissue from the lateral ventricles was obtained from patients with clinically diagnosed, neuro-pathologically confirmed progressive MS $(n=16)$ and non-neuroinflammatory control cases $(n=7)$ by rapid autopsy (Netherlands Brain Bank and Multiple Sclerosis Society Tissue Bank, funded by the Multiple Sclerosis Society of Great Britain and Northern Ireland, registered charity 207,495). All patients and controls, or their next of kin, had given informed consent for autopsy and use of their brain tissue for research purposes. Relevant clinical information was retrieved from the medical records and is summarized in Table 1.

\section{Immunohistochemistry}

$\mathrm{CP}$ tissue was sliced in $5 \mu \mathrm{m}$ sections, deparaffinized and washed with MilliQ (Millipore). Heat-mediated antigen retrieval was performed in the corresponding buffer (Table 2). Sections were cooled on ice for $30 \mathrm{~min}$ and washed with phosphate buffered saline (PBS). Subsequently, sections were blocked with PBS containing 10\% normal serum (from the host of the secondary antibody) or bovine serum albumin (BSA, Fraction V, Roche Diagnostics; when using antibodies from multiple hosts) and 0.05\% Tween20 (Sigma-Aldrich) for $20 \mathrm{~min}$. Primary antibodies (Table 2) were diluted in PBS containing 1\% normal serum or BSA and $0.05 \%$ Tween 20 , and incubated in the dark overnight at $4{ }^{\circ} \mathrm{C}$ or for $1 \mathrm{~h}$ at room temperature. Then, sections were washed with PBS. Alexa fluorophoreconjugated secondary antibodies (Thermo Fisher Scientific) were diluted in PBS containing 0.05\% Tween20 and incubated for $1 \mathrm{~h}$ at room temperature in the dark. After washing with PBS, sections were incubated with Hoechst (33,258, Thermo Fisher Scientific), for nuclear visualization, diluted in PBS to a final concentration of $10 \mu \mathrm{g} / \mathrm{mL}$ for 1 minute in the dark. Sections were washed with PBS, mounted with Mowiol medium and a coverslip (MenzelGlaser, thickness \#1) and stored in the dark at $4{ }^{\circ} \mathrm{C}$ until image acquisition.

\section{Image acquisition and immunostaining scoring}

After immunohistochemistry, sections were visualized using a Nikon A1R+ HD confocal galvano scanning laser microscope with 20x magnification and the NISElements software (Nikon). Three image fields per sample displaying characteristic CP morphology were picked based on the basement membrane (collagen IV), while 
Table 1 Clinical data of MS patients and non-neuroinflammatory controls

\begin{tabular}{|c|c|c|c|c|c|c|c|c|c|c|}
\hline & Sample & Gender & $\begin{array}{l}\text { Age at } \\
\text { death }\end{array}$ & $\begin{array}{l}\text { PMD } \\
\text { (h) }\end{array}$ & $\begin{array}{l}\mathrm{pH} \\
\mathrm{CSF}\end{array}$ & $\begin{array}{l}\text { Brain } \\
\text { weight } \\
\text { (g) }\end{array}$ & Diagnosis & Cause of death & $\begin{array}{l}\text { Disease } \\
\text { duration (y) }\end{array}$ & $\begin{array}{l}\text { Brain } \\
\text { Bank }\end{array}$ \\
\hline \multirow[t]{7}{*}{ Control } & 1 & m & 56 & $14: 00$ & 7.03 & 1323 & $\begin{array}{l}\text { Non-demented } \\
\text { control }\end{array}$ & Terminal congestive heart failure & na & NBB \\
\hline & 2 & f & 78 & $7: 10$ & 6.32 & 1120 & $\begin{array}{l}\text { Non-demented } \\
\text { control }\end{array}$ & Legal euthanasia & na & NBB \\
\hline & 3 & f & 60 & $8: 10$ & 6.58 & 1310 & $\begin{array}{l}\text { Non-demented } \\
\text { control }\end{array}$ & Metastasized mammacarcinoma & na & NBB \\
\hline & 4 & f & 80 & 7:04 & 6.2 & 1450 & $\begin{array}{l}\text { Non-demented } \\
\text { control }\end{array}$ & Legal euthanasia with metastasis & na & NBB \\
\hline & 5 & m & 93 & $7: 40$ & 6.2 & 1155 & Dementia with s.i.c.c. & Heart failure & na & NBB \\
\hline & 6 & m & 73 & $8: 00$ & 5.37 & 1553 & $\begin{array}{l}\text { Non-demented } \\
\text { control }\end{array}$ & $\begin{array}{l}\text { Invasive fungal infection and } \\
\text { bacterial pneumonia }\end{array}$ & na & NBB \\
\hline & 7 & f & 95 & 4:21 & 6.59 & 1169 & $\begin{array}{l}\text { Non-demented } \\
\text { control }\end{array}$ & Ileus, palliative care & na & NBB \\
\hline \multirow[t]{16}{*}{$\begin{array}{l}\text { Progressive } \\
\text { MS }\end{array}$} & 8 & m & 66 & 10:55 & 7.28 & na & $\begin{array}{l}\text { Multiple sclerosis } \\
\text { (PPMS) }\end{array}$ & Legal euthanasia & 25 & NBB \\
\hline & 9 & m & 70 & $6: 55$ & 6.51 & 1230 & $\begin{array}{l}\text { Multiple sclerosis } \\
\text { (SPMS) }\end{array}$ & $\begin{array}{l}\text { Acute heart failure, Clostridium } \\
\text { difficile colitis }\end{array}$ & 47 & NBB \\
\hline & 10 & f & 74 & $7: 50$ & 6.4 & 975 & $\begin{array}{l}\text { Multiple sclerosis } \\
\text { (SPMS) }\end{array}$ & Legal euthanasia & 50 & NBB \\
\hline & 11 & f & 60 & 9:25 & 7 & 1295 & $\begin{array}{l}\text { Multiple sclerosis } \\
\text { (SPMS) }\end{array}$ & $\begin{array}{l}\text { Legal euthanasia with atrial } \\
\text { fibrillations and fatigue }\end{array}$ & 22 & NBB \\
\hline & 12 & m & 54 & $7: 55$ & 6.6 & 1365 & $\begin{array}{l}\text { Multiple sclerosis } \\
\text { (SPMS) }\end{array}$ & Legal euthanasia & 21 & NBB \\
\hline & 13 & f & 57 & $10: 40$ & 6.76 & 1145 & $\begin{array}{l}\text { Multiple sclerosis } \\
\text { (SPMS) }\end{array}$ & Legal euthanasia with ataxia & 25 & NBB \\
\hline & 14 & m & 82 & $8: 05$ & 6.7 & 1465 & $\begin{array}{l}\text { Multiple sclerosis } \\
\text { (PPMS) }\end{array}$ & Pneumonia & 44 & NBB \\
\hline & 15 & m & 75 & 9:10 & 6.24 & 1140 & $\begin{array}{l}\text { Multiple sclerosis } \\
\text { (SPMS) }\end{array}$ & na & na & NBB \\
\hline & 16 & f & 83 & $7: 40$ & 6.54 & 1090 & $\begin{array}{l}\text { Multiple sclerosis } \\
\text { (PPMS) }\end{array}$ & Ovarium carcinoma & 34 & NBB \\
\hline & 17 & f & 66 & 9:30 & 6.7 & 1243 & $\begin{array}{l}\text { Multiple sclerosis } \\
\text { (SPMS) }\end{array}$ & Legal euthanasia & 25 & NBB \\
\hline & 18 & f & 49 & 24:00 & 6.8 & 1006 & $\begin{array}{l}\text { Multiple sclerosis } \\
\text { (PPMS) }\end{array}$ & Multiple sclerosis & na & UK \\
\hline & 19 & f & 39 & 15:00 & na & 998 & $\begin{array}{l}\text { Multiple sclerosis } \\
\text { (SPMS) }\end{array}$ & Pulmonary embolism, pneumonia & 9 & UK \\
\hline & 20 & $\mathrm{~m}$ & 57 & 21:00 & na & 1280 & $\begin{array}{l}\text { Multiple sclerosis } \\
\text { (PPMS) }\end{array}$ & Multiple sclerosis & na & UK \\
\hline & 21 & $\mathrm{~m}$ & 63 & $10: 00$ & 6.52 & 1614 & $\begin{array}{l}\text { Multiple sclerosis } \\
\text { (PMS, likely PPMS) }\end{array}$ & $\begin{array}{l}\text { Aspiration pneumonia and sepsis; } \\
\text { advanced MS }\end{array}$ & 30 & NBB \\
\hline & 22 & f & 61 & 08:04 & 6.41 & 1155 & $\begin{array}{l}\text { Multiple sclerosis } \\
\text { (SPMS) }\end{array}$ & Urosepsis and hydronepfronis & 22 & NBB \\
\hline & 23 & $\mathrm{~m}$ & 70 & 05:10 & 6.82 & 1181 & $\begin{array}{l}\text { Multiple sclerosis } \\
\text { (SPMS) }\end{array}$ & $\begin{array}{l}\text { Dehydration, decompensation } \\
\text { cordis, MS; palliative sedation }\end{array}$ & 21 & NBB \\
\hline
\end{tabular}

PMD Post-mortem delay, $f$ Female, $m$ Male, na Not available, s.i.c.c Senile involutive cortical changes, NBB Netherlands Brain Bank, UK Multiple Sclerosis Society Tissue Bank

blinded to the other fluorophore channels before final imaging. Because of the abundance of cells in the Iba1/ MHCII panel, only one image field was captured. To improve quantification of the Iba1/MHCII and CD66b stainings, a z-stack was created consisting of nine onemicrometre steps. ImageJ was used to process the images, outline the different $\mathrm{CP}$ compartments, manually count the cells and quantify the tissue area [1]. This 
Table 2 Antibody details

\begin{tabular}{|c|c|c|c|c|c|c|}
\hline Target & Marker & Host & Clonality (clone) & $\begin{array}{l}\text { End } \\
\text { concentration }\end{array}$ & Company (catalog number) & $\begin{array}{l}\text { Antigen } \\
\text { retrieval }\end{array}$ \\
\hline APCs & $\mathrm{MHCll}$ & Mouse & Monoclonal (LN3) & $6.8 \mu \mathrm{g} / \mathrm{mL}$ & Hybridoma & Citrate \\
\hline B cells & CD19 & Rat & $\begin{array}{l}\text { Monoclonal } \\
\text { (6OMP31) }\end{array}$ & $0.5 \mu \mathrm{g} / \mathrm{mL}$ & Thermo Fisher Scientific (14-0194-82) & Citrate \\
\hline $\begin{array}{l}\text { Basement } \\
\text { membrane }\end{array}$ & Collagen IV & Rabbit & Polyclonal & $3.3 \mu \mathrm{g} / \mathrm{mL}$ & Abcam (ab6586) & Tris or citrate \\
\hline CD4+ T cells & CD4 & Rabbit & $\begin{array}{l}\text { Monoclonal } \\
\text { (EPR6855) }\end{array}$ & $1.1 \mu \mathrm{g} / \mathrm{mL}$ & Abcam (ab133616) & Tris \\
\hline CD8+ T cells & CD8 & Mouse & $\begin{array}{l}\text { Monoclonal (C8/ } \\
\text { 144B) }\end{array}$ & $0.157 \mu \mathrm{g} / \mathrm{mL}$ & Dako (M7103) & Tris \\
\hline Endothelial cells & Biotinylated UEA & Europaeus & s Agglutinin I (UEA I) & $2.0 \mu \mathrm{g} / \mathrm{mL}$ & Vector laboratories (B-1065) & Tris \\
\hline Granulocytes & $\begin{array}{l}\text { CD66b (A647 } \\
\text { label) }\end{array}$ & Mouse & Monoclonal (G10F5) & $4.5 \mu \mathrm{g} / \mathrm{mL}$ & $\begin{array}{l}\text { Novus Biologicals (NB100- } \\
\text { 77808AF647) }\end{array}$ & Citrate \\
\hline Myeloid cells & Iba1 & Goat & Polyclonal & $1.0 \mu \mathrm{g} / \mathrm{mL}$ & Abcam (ab5076) & Citrate \\
\hline Plasma cells & CD138 & Mouse & Monoclonal (Ml15) & $\begin{array}{l}\text { Not available (1: } \\
\text { 50) }\end{array}$ & $\begin{array}{l}\text { Thermo Fisher Scientific (MA5- } \\
\text { 12400) }\end{array}$ & Citrate \\
\hline T cells & CD3 & Mouse & Monoclonal (F7.2.38) & $2.8 \mu \mathrm{g} / \mathrm{mL}$ & Dako (M7254) & Tris \\
\hline T cells & CD3 & Rabbit & Polyclonal & $3.0 \mu \mathrm{g} / \mathrm{mL}$ & Dako (A0452) & Tris \\
\hline
\end{tabular}

APCs Antigen-presenting cells, Tris: $10 \mathrm{mM}$ Tris / $1 \mathrm{mM}$ EDTA, pH 9; Citrate: $10 \mathrm{mM}$ sodium citrate buffer, pH 6

method allows for a quantitative scoring of the immune cells in each of the CP compartments. Imaging and scoring were performed blinded.

For visualization of the interaction between MHCII+ cells with T cells we used a Leica TCS SP8 microscope (Leica Microsystems) and the Leica Application Suite Advanced Fluorescence software (Leica Microsystems). Fifteen non-circulating CD3+ T cells were selected per sample and assessed for interaction with MHCII+ cells.

\section{Data analysis}

Data were analyzed using $\mathrm{R}$ version $3.4 .2[29,30]$. For the immune cell quantification, the number of identified immune cells was corrected for analyzed tissue area to calculate cell density. The obtained data were assessed for normality using a Shapiro-Wilk test. In the case of normality, differences between groups were evaluated with a Welch Two Sample t-test. Alternatively, a Wilcoxon rank sum test was applied. Data are reported as the median. Correlations were calculated using the Pearson correlation coefficient. PCA was performed in R using the density of $\mathrm{CP}$ (stromal and epitheliumassociated) MHCII+ macrophages, MHCII- macrophages, dendritic cells (DCs), total T cells, CD4+ T cells, CD8+ T cells, B cells or plasma cells, granulocytes and the percentage of $\mathrm{T}$ cells interacting with MHCII+ cells.

\section{Results}

Macrophages and dendritic cells densely populate the CP of both progressive MS patients and controls

In order to characterize the density and location of the immune cell populations within the $\mathrm{CP}$, we performed immunohistochemical analysis of well characterized post-mortem CP of progressive MS cases and nonneuroinflammatory control cases (patient details in Table 1). The visualized $\mathrm{CP}$ area was divided into three compartments using the epithelial and endothelial basement membranes (stained by collagen IV) to guide this division. The cellular location was defined as either in the circulation ("vessel", excluded from the analyses; Additional file 2: Figure S1), in the stromal compartment ("stroma") or associated to the epithelium ("epithelium") (Fig. 1a).

To assess the presence of macrophages and dendritic cells (DCs), we immunolabelled CP tissue with Iba1 and MHCII (HLA-DR). The CP of both control and progressive MS cases was densely populated by macrophages (Iba1+ cells) and DCs (defined as Iba1- MHCII+ cells) (Fig. 1b-f). Most of the macrophages were positive for MHCII (Fig. 1c), suggesting their involvement in local antigen presentation; however, a small subset of stromal macrophages was negative for MHCII (Fig. 1b-d). Both macrophages and DCs were mainly located in the stromal compartment (Fig. 1d and f). No differences in macrophage or DC densities were observed between progressive MS and control cases in any of the CP compartments (Fig. 1c-f). In summary, macrophages and DCs densely populate the CP of both controls and progressive MS patients.

\section{CD8+ T cells are more abundant in progressive MS CP compared to control CP}

As $\mathrm{T}$ cells have previously been shown to enter the CNS through the CP in EAE [23], we next assessed the density and distribution of $\mathrm{T}$ lymphocytes in the $\mathrm{CP}$ of 


\section{a}
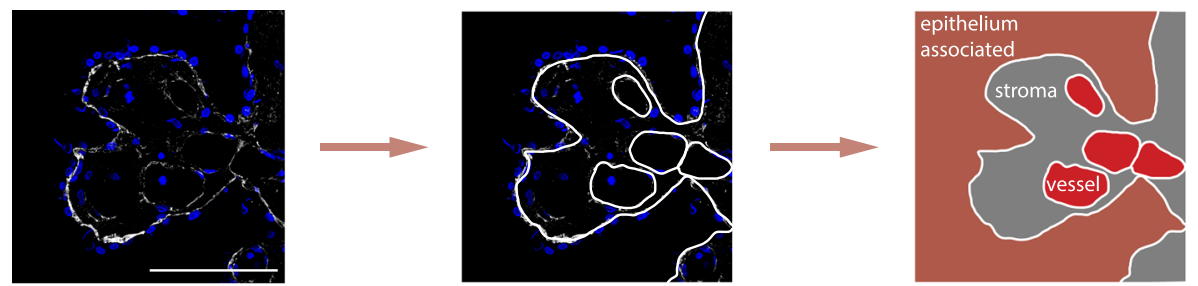

b
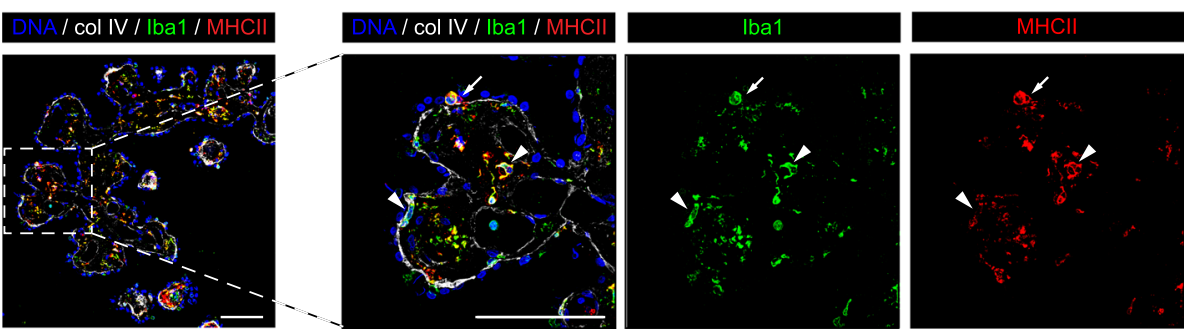

C
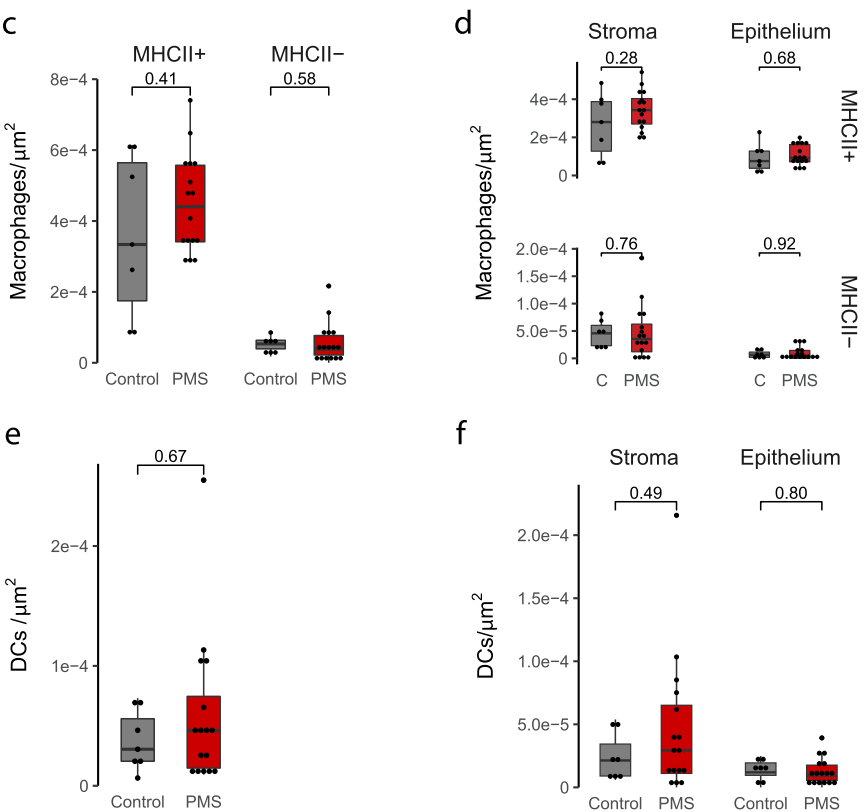

Fig. 1 Density of macrophages and DCs is similar in the CP of progressive MS patients and controls. a Example of the compartmentalization of the CP tissue. Using the basement membrane as guidance (collagen IV, in white), we discern the stromal and epithelium-associated cells (which together are the CP cells), and exclude the circulating cells located in the vessels. $\mathbf{b}$ Maximum projection of an image of a CP immunolabeled with Ibal, MHCII and collagen IV. Right panel shows a higher magnification of the image. White arrowheads point to one MHCII+ and one MHCIImacrophage (Iba1+) in the CP stroma; white arrow points to a dendritic cell (DC; Iba1- MHCll+) associated to the epithelium. $\mathbf{c}$ Density of CP macrophages (MHCll+ and $\mathrm{MHCll}-$ ) in control and progressive MS (Wilcoxon rank sum test with continuity correction). $\mathbf{d}$ Density of CP macrophages in the different CP compartments (Welch Two Sample t-test and Wilcoxon rank sum test with continuity correction). e Density of CP DCs in control and progressive MS (Wilcoxon rank sum test). $\mathbf{f}$ Density of CP DCs in the different CP compartments (Wilcoxon rank sum test and Welch Two Sample t-test). Col IV: collagen IV; PMS: progressive MS. Scale bars are $100 \mu \mathrm{m}$

control and progressive MS patients. CD3+ T cells were present in the CP of both control and progressive MS patients (Fig. 2). Importantly, the density of CD3+ T cells was significantly higher in the $\mathrm{CP}$ of progressive MS $\left(4.19 \mathrm{e}-5\right.$ cells $\left./ \mu \mathrm{m}^{2}\right)$ compared to control $\mathrm{CP}$ (1.15e-5 cells $/ \mu \mathrm{m}^{2}$; Fig. 2b). This difference was mainly due to a higher $\mathrm{T}$ cell density in the stromal compartment, where the vast majority of $\mathrm{T}$ cells were located (Fig. 2c).

Previous research showed that $\mathrm{T}$ lymphocytes can infiltrate the mouse $\mathrm{CP}$ for re-activation and proliferation [28]. To address this phenomenon in the human CP, we studied the spatial association between $\mathrm{CD} 3+\mathrm{T}$ cells and MHCII+ APCs in the CP stroma. The presence of T 
a
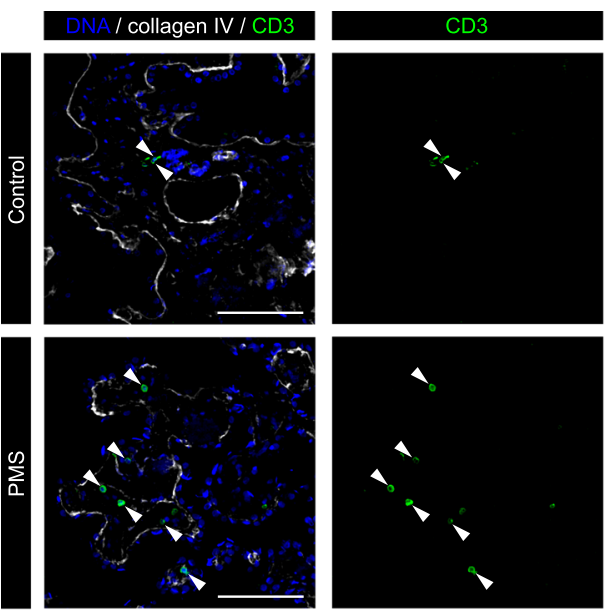

C
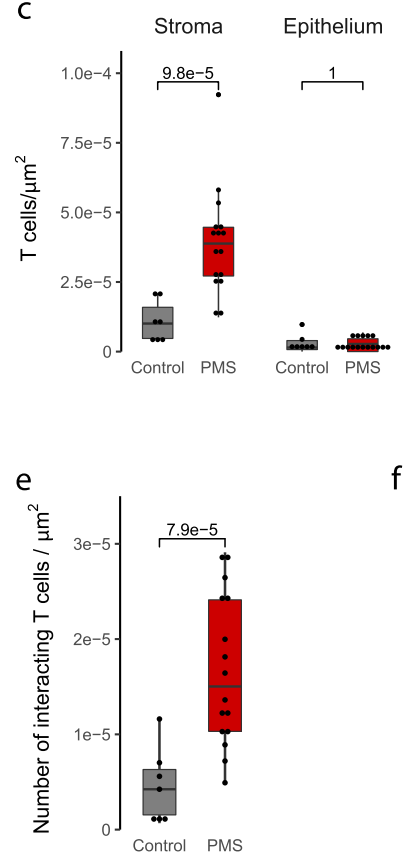

b

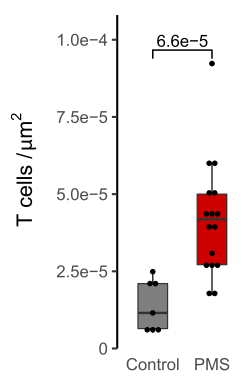

d

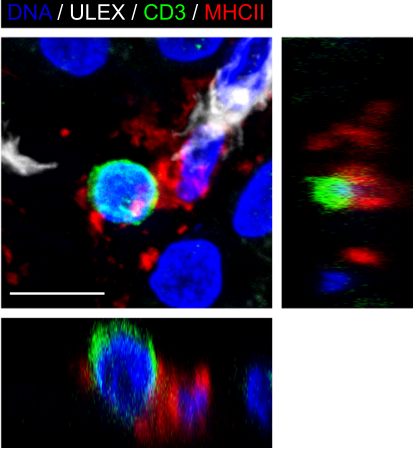

g

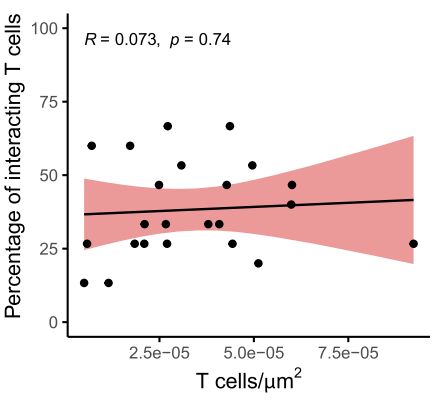

Fig. 2 T cell density is higher in the CP stroma of progressive MS patients than in the control CP, and they interact with APCs. a Representative images of the control and progressive MS CP immunolabeled with CD3 and collagen IV. White arrowheads point to stromal CD3+ T cells. Scale bars are $100 \mu \mathrm{m}$. b Density of CP T cells in the CP of control and progressive MS cases (Welch Two Sample t-test). c Density of CP T cells in the different CP compartments (Wilcoxon rank sum test). $\mathbf{d}$ Representative image of a T cell (CD3+, green) in close contact with an APC (MHCII+, red); vessels are visualized with UEA I (white). Maximum projection is accompanied by the orthogonal views. Scale bar is $10 \mu \mathrm{m}$. e Absolute density of T cells in close contact with MHCII+ APCs in the CP of control and progressive MS patients, calculated by applying the percentage of T cells that were interacting with APCs to the total density of T cells in their respective samples (Welch Two Sample t-test). f Percentage of T cells interacting with APCs in the CP of control and progressive MS patients, defined as the CP T cells located directly adjacent to MHCII+ cells (Welch Two Sample t-test). $\mathbf{g}$ Lack of correlation between interacting T cells and the total CP T cells in each sample (Pearson's correlation). PMS: progressive MS

cells adjacent to APCs was commonly observed in both control and progressive MS (Fig. 2d, Additional file 2: Figure S2a-b and Additional file 3: Movie 1). While the calculated absolute number of interacting $\mathrm{T}$ cells was higher in progressive MS than in control (Fig. 2e), this was due to the higher density of $\mathrm{T}$ cells and there were no differences in the percentage of interacting $\mathrm{T}$ cells between the groups (Fig. 2f). Indeed, there was no correlation between the percentage of interacting $\mathrm{T}$ cells and the corresponding density of total CP T cells in the MS group (Fig. $2 \mathrm{~g}$ ). 
To further define the phenotype of these $\mathrm{T}$ cells, we analyzed $\mathrm{CD} 4+$ helper and $\mathrm{CD} 8+$ cytotoxic $\mathrm{T}$ cell subsets, with the aid of the endothelial marker UEA I to exclude circulating cells located in the vessels. Both $\mathrm{CD} 4+$ and $\mathrm{CD} 8+\mathrm{T}$ cells were present in the $\mathrm{CP}$ of all cases, but only $\mathrm{CD} 8+\mathrm{T}$ cell density was significantly higher in progressive MS patients $2.83 \mathrm{e}-5$ cells $\left./ \mu \mathrm{m}^{2}\right)$ relative to controls $(1.53 \mathrm{e}-5$ cells $/ \mu \mathrm{m}^{2}$; Fig. $3 \mathrm{a}$ and b). Both CD $4+$ and CD $8+\mathrm{T}$ cells were found in close contact with APCs (Fig. 3c, Additional file 2: Figure S2c). Together, our data indicate that $\mathrm{T}$ cells are present in the $\mathrm{CP}$, where they interact with APCs in both controls and progressive MS patients, and that there is a higher density of CD8+ $\mathrm{T}$ cells in progressive MS patients relative to controls.
B cells and plasma cells are virtually absent from the CP $\mathrm{B}$ cells are implicated in the pathogenesis of progressive MS, as demonstrated by the efficacy of CD20-targeted therapies $[7,8,13,25]$. In the meninges, $\mathrm{B}$ cells and plasma cells are present in the follicle-like structures found in some progressive MS patients [22, 26], and there are more $\mathrm{B}$ cells in the CSF of progressive MS patients relative to controls [10]. Thus, we set out to investigate whether B cells and plasma cells are present in the $\mathrm{CP}$ of progressive MS patients and controls. In most MS patients and all controls, we did not observe any B cells (marked by CD19) and/or plasma cells (marked by CD138). In one progressive MS patient, a double positive cell for CD19 and CD138 was identified in the stroma (Fig. 4). Only one CD19+ CD138- B cell was detected in our patient cohort (Fig. 4a-b). In sum, B cells

a
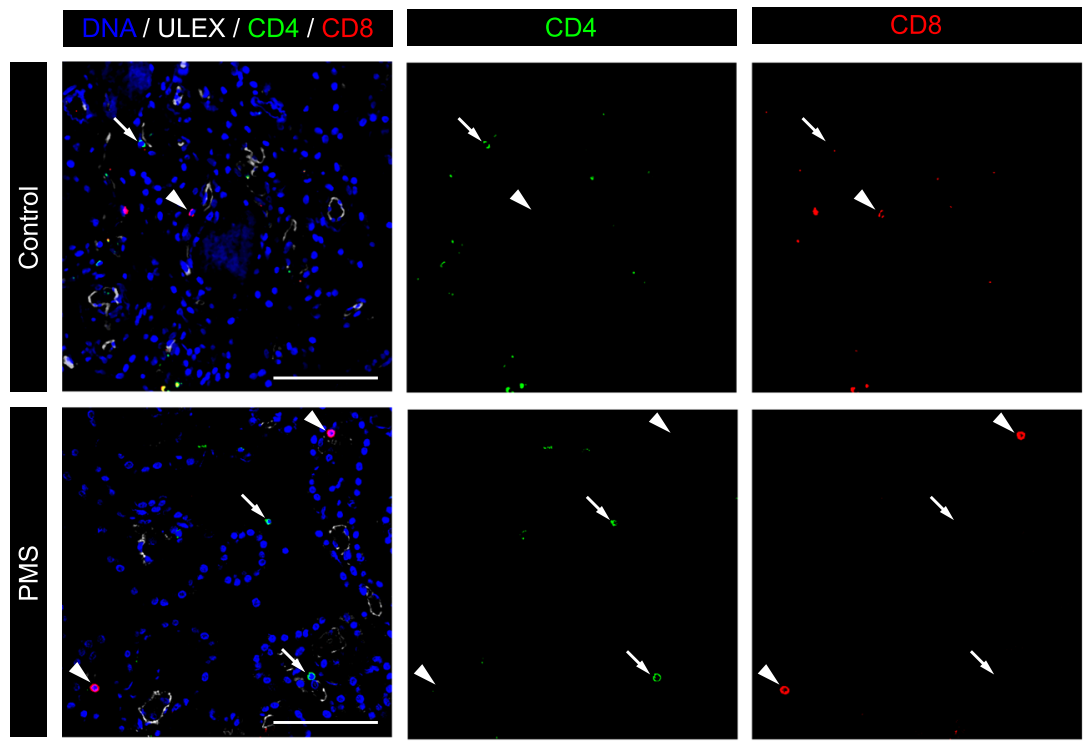

b

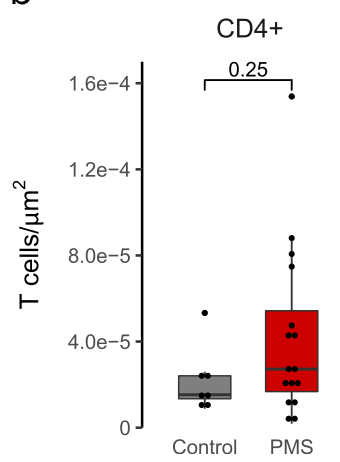

CD8+
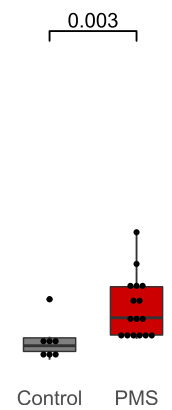

$C$
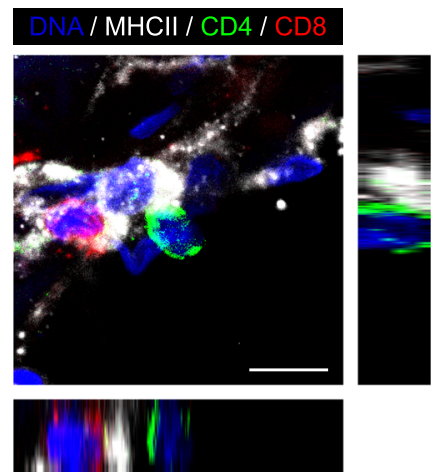

Fig. 3 CD8+ T cell density is significantly higher in the CP stroma of progressive MS patients relative to that of controls. a Representative images of the progressive MS and control CP immunolabeled with CD4 (green), CD8 (red) and UEA I (white). White arrows point to CD4+ T cells, while white arrowheads point to CD8+ T cells. b Density of CP CD4+ and CD8+ T cells in the CP of control and progressive MS patients (Wilcoxon rank sum test). Scale bars are $100 \mu \mathrm{m}$. c Representative image of a CD4+ T cell (green) and a CD8+ T cell (red) in close contact with an APC (MHCII+, white). Maximum projection is accompanied by the orthogonal views. Scale bar is $10 \mu \mathrm{m}$. PMS: progressive MS 
a
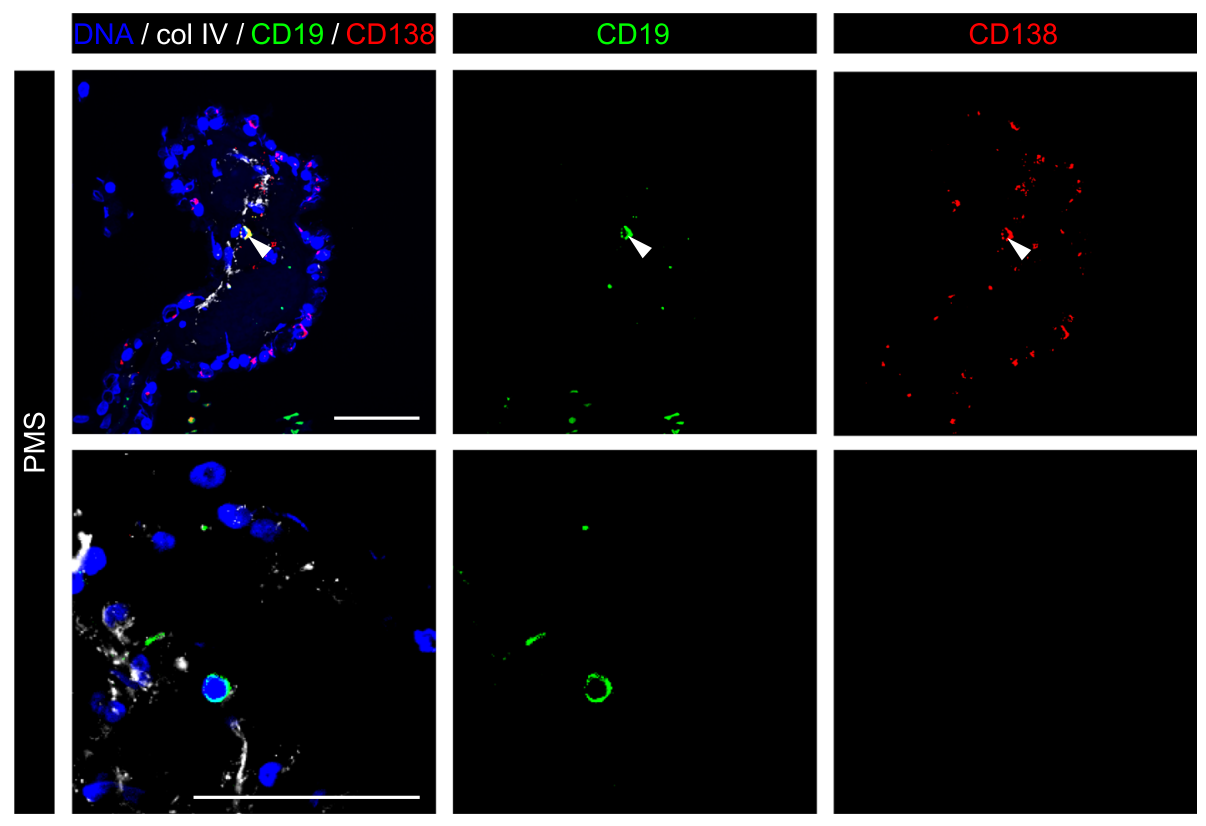

b

C
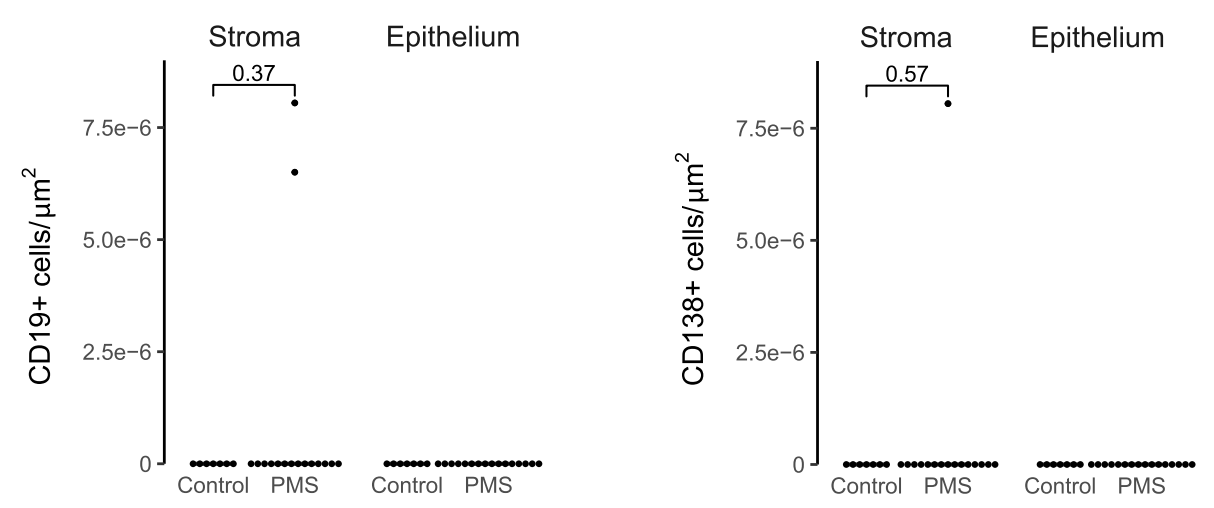

Fig. 4 B and plasma cells are virtually absent from the CP. a Examples of CD19+ and CD138+ cells in the CP of progressive MS patients; basement membrane was immunolabeled with collagen IV. White arrowhead in the top panel points to a CD19+ CD138+ cell; in the lower panel, a CD19+ B cell is seen. $\mathbf{b}$ Density of CP CD19+ cells in the different CP compartments (Wilcoxon rank sum test with continuity correction). c Density of CP CD138+ cells in the different CP compartments (Wilcoxon rank sum test with continuity correction). PMS: progressive MS. Scale bars are $50 \mu \mathrm{m}$

and plasma cells are virtually absent from the CP of both progressive MS patients and controls.

\section{Granulocytes are more abundant in the $\mathrm{CP}$ of progressive} MS patients compared to control CP

The role of granulocytes has been underappreciated in MS pathology [33]. We studied the presence of granulocytes in the $\mathrm{CP}$ using the marker CD66b. As expected due to their abundance in blood, most of the granulocytes were detected in the vessels (Additional file 2: Figure S1f). In progressive MS patients, the density of non-circulating granulocytes was significantly higher than in controls $\left(5.26 \mathrm{e}-6 \mathrm{cells} / \mu \mathrm{m}^{2}\right.$ vs 0 cells $/ \mu \mathrm{m}^{2}$; Fig. $\left.5 \mathrm{~b}\right)$. This difference was mainly due to the stromal compartment (Fig. 5c), although in the progressive MS CP epithelium there was also a trend to a higher density of granulocytes compared to the control. Preliminary stainings show that most of the granulocytes were neutrophils, as shown by their expression of elastase (Additional file 2: Figure S3). These findings indicate that granulocyte infiltration is apparent in the CP of progressive MS patients.

\section{Discussion}

By using human post-mortem $\mathrm{CP}$ tissue in combination with immunohistochemistry and confocal microscopy, we 


\section{a}
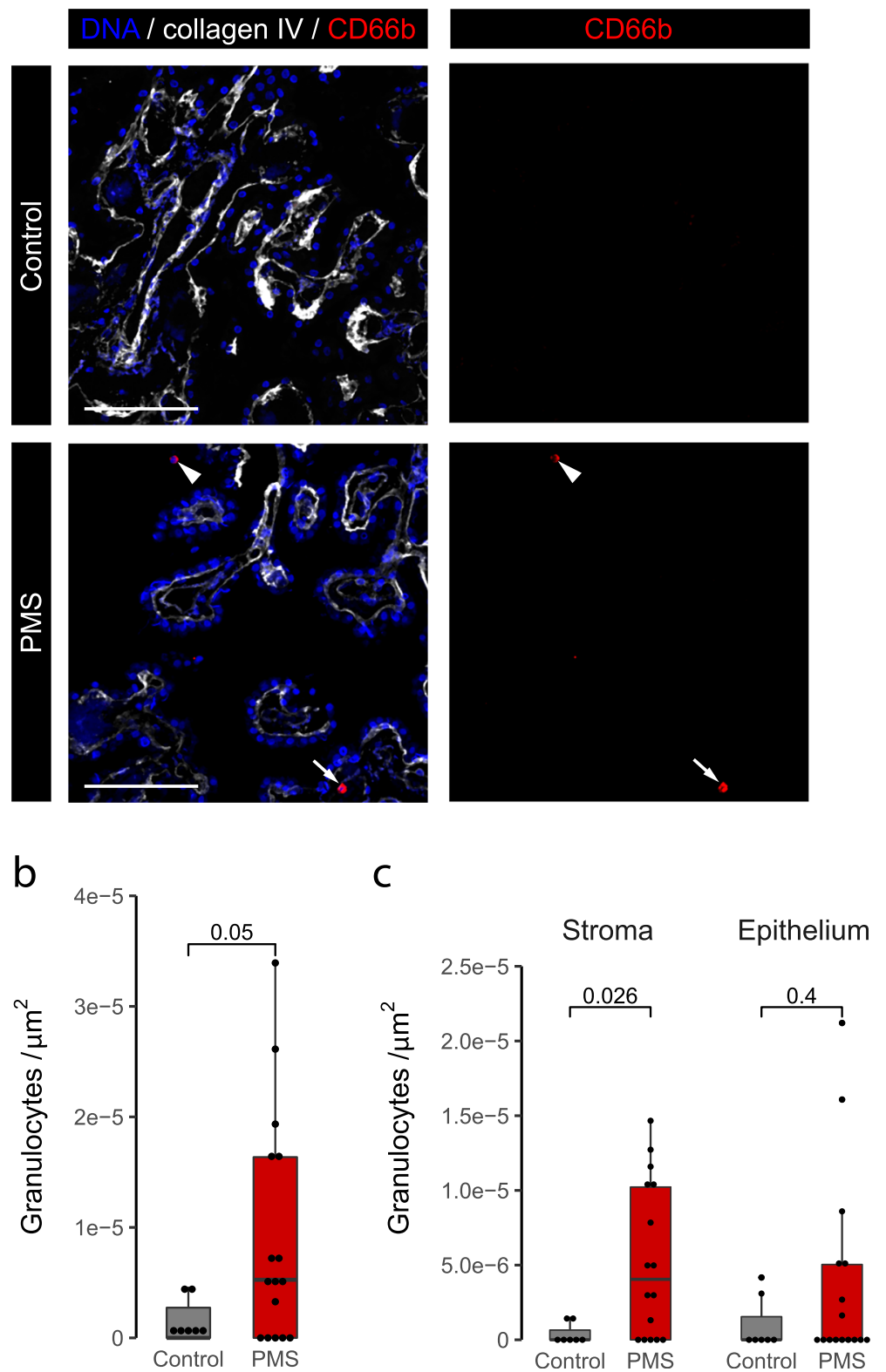

Fig. 5 Granulocyte density is higher in the CP of progressive MS patients relative to the control CP. a Maximum projection image of a progressive MS and a control CP immunolabeled with CD66b (red) and collagen IV (white). White arrowhead points to a granulocyte associated with the epithelium and white arrow points to a stromal granulocyte in the progressive MS case. $\mathbf{b}$ Density of CP granulocytes in the CP of control and progressive MS cases (Wilcoxon rank sum test with continuity correction). c Density of CP granulocytes in the different CP compartments (Wilcoxon rank sum test with continuity correction). PMS: progressive MS. Scale bars are $100 \mu \mathrm{m}$

here provide a comprehensive overview of immune cell populations present in the $\mathrm{CP}$ of non-neuroinflammatory controls and progressive MS cases, both in terms of abundance and of their location within the different CP compartments (summarized in Fig. 6 and Additional file 1: Table S1). For the first time, we show that both CD8+ T cells and granulocytes are more abundant in the $\mathrm{CP}$ stroma of progressive MS cases compared to controls. Around one third of the $\mathrm{T}$ cells appeared to be in close contact with APCs in the CP regardless of disease status, suggesting that local antigen presentation is a constitutive event in the CP. Furthermore, we show that macrophages, particularly those expressing MHCII, and DCs are abundant in CP of both MS patients and controls, with the 


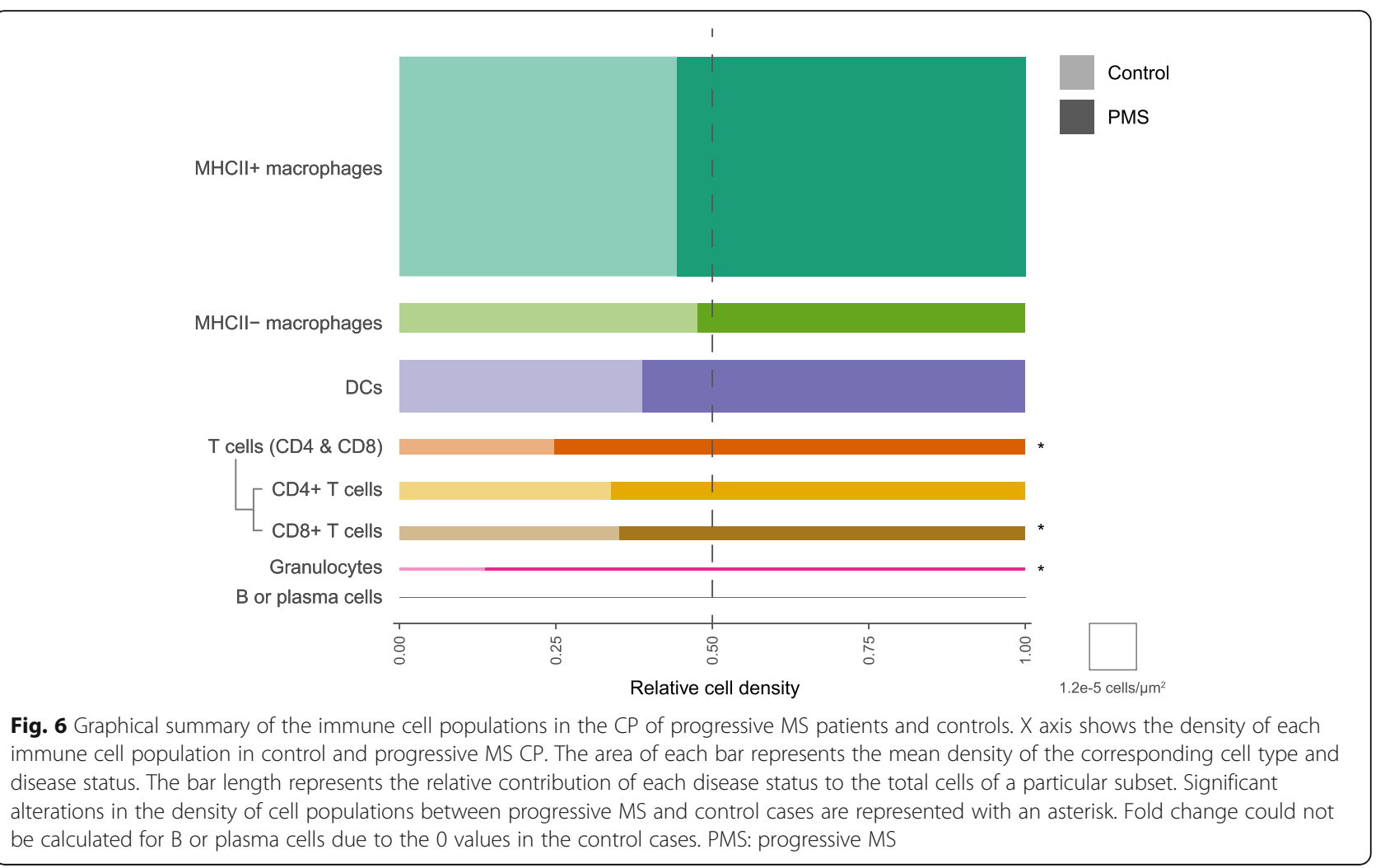

majority located in the stroma but also associated with the epithelium. In contrast, B and plasma cells were rarely observed in both the MS and control CP.

The $\mathrm{CP}$ is a strategically located, highly vascularized structure within the brain ventricles with CNS homeostatic properties. The CP acts as a bidirectional immunosurveillance system by means of the BCSFB [28]. To date, relatively little is known about the immune cell populations in the human CP under normal and inflammatory conditions. We here provide a detailed characterization of the main immune cell populations in the $\mathrm{CP}$ of controls and progressive MS patients, which can be a resource for researchers in the field of brain barriers and MS, while helping to better understand the inflammatory processes in the progressive phases of MS.

$\mathrm{T}$ cells play a central role in the pathogenesis of MS [15, 19]. Here, we observed that the $\mathrm{CP}$ presents a higher density of $\mathrm{T}$ cells in MS patients relative to controls, in line with a previous study of Vercellino and co-workers [32]. We further demonstrated that $\mathrm{T}$ lymphocytes are also present in control individuals, as reported before [16]. In contrast, another study found no T cells in control CP [32], which may be explained by a small number of control cases used in that study. $\mathrm{T}$ cells are predominantly localized in the stromal compartment of the CP. Stromal T lymphocytes may be infiltrated from the periphery into the CNS [23], migrated from the CSF into the CP for re-activation [28] or remain in the $\mathrm{CP}$ as tissue resident $\mathrm{T}$ cells. The relative scarcity of epithelium associated $\mathrm{T}$ cells, together with the lack of changes in $\mathrm{T}$ cell numbers in the CSF of progressive MS patients [10], supports the view that $\mathrm{T}$ cells in the $\mathrm{CP}$ of progressive MS are restricted to the stromal compartment and do not cross the BCSFB at the CP. However, we cannot exclude the possibility that subtle differences in epithelial $\mathrm{T}$ cell density are missed due to the brevity of the migration process and the relative small size of the epithelial compartment, which result in a low chance of detecting them. CD8+ $\mathrm{T}$ cells are the predominant $\mathrm{T}$ cell subtype in MS lesions [3] and we observed accumulation of CD8+ T cells in the progressive MS CP. While CD8+ T cells within the brain have detrimental effects on CNS cells, those restricted to the CNS borders may exert immunosuppressive effects [14, 15, 31], or simply reside as tissue memory $\mathrm{T}$ cells as a result of previous inflammatory processes.

The role of granulocytes in MS pathology has been underappreciated as they are rarely reported in MS lesions $[2,33]$. In RRMS, the number of neutrophils in the CSF decreases with disease duration [18]; in contrast, PPMS subjects have more granulocytes than RRMS patients in the CSF [10]. Interestingly, our unpublished findings showed that the neutrophil chemoattractant gene CXCL2 is upregulated in the $\mathrm{CP}$ of progressive MS patients. Here, we observed more granulocytes in the $\mathrm{CP}$ of progressive MS patients compared to the $\mathrm{CP}$ from controls. Because granulocytes have a particularly short lifespan, our results point to a continuous infiltration from the peripheral circulation at this chronic stage 
of the disease. Although granulocytes are typically regarded as innate immune cells detrimental for tissue repair, the release of reactive oxygen species and degranulation can also have a regulatory effect in the adaptive immune system. As such, neutrophils exert an immunosuppressive effect on $\mathrm{T}$ cell responses to myelin [34]. Whether they play a similar role in the progressive MS CP and thereby restrict $\mathrm{T}$ cell infiltration at the $\mathrm{CP}$ needs to be further elucidated.

Macrophages and DCs are the predominant immune cell type in the CP stroma. Their antigen-presenting capacity is illustrated by the expression of MHCII on their surface. In addition to their stromal location, we observed that macrophages and DCs were associated with the $\mathrm{CP}$ epithelium, either protruding among epithelial cells or associated with the apical surface of the epithelium (known as Kolmer cells or epiplexus macrophages), which confirms and extends earlier observations [11, 27, 32]. These epitheliumassociated immune cells at the BCSFB are likely a bridge between the peripheral and CNS immune systems [11, 12]. Thus, the CP may have constitutive functions in CNS homeostasis through this niche of macrophages and DCs, such as local presentation of CNS antigens.

Our study revealed the virtual absence of $\mathrm{B}$ cells and plasma cells in the CP. Importantly, our results are in line with previous research, which described very rare CD138+ plasma cells and an absence of CD20+ B cells [32]. Thus, the $\mathrm{CP}$ does not appear to be an initial CNS-entry site for B cells during the progressive phase of MS. Instead, B cells present in the meninges of progressive MS patients $[22,26]$ may represent the primary source of infiltrating B cells into the CSF.

This study is constrained by the availability of human $\mathrm{CP}$ tissue. Thus, the variability in the immune populations between donors (Additional file 2: Figure S4) may have hindered the detection of subtle differences. It would be interesting to explore the $\mathrm{CP}$ immune cell composition of RRMS patients, however we could not obtain high quality CP samples from RRMS patients. Despite the heterogeneity in immune cell densities among the patients, we did not find differences between PPMS and SPMS patients (Additional file 2: Figure S5). Although PPMS and SPMS present different disease courses, in both progressive forms of MS neurodegeneration predominates over acute inflammation. Accordingly, a moderately inflamed status is seen in the CP of both PPMS and SPMS patients. Although we tried to use consensus cellular markers, no single marker can identify human DCs. By defining DCs as MHCII+ Iba1-, we could not exclude other APCs, such as B cells or activated $\mathrm{T}$ cells. However, considering the scarcity of $\mathrm{B}$ cells and the lack or subtle expression of MHCII by $\mathrm{T}$ cells in the $\mathrm{CP}$, we expect this error to be negligible. Lastly, the use of fixed post-mortem material provides only a snapshot of a dynamic process that cannot fully reflect the progression of the disease.
In summary, this study provides a detailed characterization of the density and location of immune cell populations present in the human $\mathrm{CP}$, as well as alterations thereof in progressive MS. The presence of immune cells in nonneuroinflammatory controls highlights the role of the $\mathrm{CP}$ in immune surveillance and homeostasis. Further, we provide insight into the involvement of the inflammatory component of the CP in progressive MS. Particularly, the abundance of $\mathrm{T}$ cells and granulocytes at the $\mathrm{CP}$ in progressive MS patients implicate both the adaptive and innate immune systems in the chronic progressive phases of MS. However, their restriction to the stromal compartment argues against the $\mathrm{CP}$ as a major entry route of immune cells into the CNS during progressive MS. Future research is warranted to unravel the functional consequences of the immune changes in the $\mathrm{CP}$, and how these may in turn affect the CNS of MS patients.

\section{Supplementary information}

Supplementary information accompanies this paper at https://doi.org/10. 1186/s40478-020-0885-1.

Additional file 1: Table S1. Density of CP (stromal and epitheliumassociated) immune cell populations in control and progressive MS patients.

Additional file 2: Figure S1. Immune cells located in the vessel compartment of the CP of progressive MS patients and controls. a) Iba1+ cells and their MHCll expression. b) Iba1- MHCll+ cells. c) CD3+ T cells. d) CD19+ B cells. e) CD138+ plasma cells. f) CD66b + granulocytes (Wilcoxon rank sum test with continuity correction). C: control; PMS: progressive MS. Figure S2. T cells in close contact with APCs in the CP stroma. a) Representative images of the CP immunolabeled with CD3 (green) and MHCII (red); vessels are visualized with UEA I (white). White arrowheads point to a CD3+ T cell in close contact with an $\mathrm{MHCll}+\mathrm{APC}$ (left panel), and to a non-interacting T cell (right panel). b) On the top panel, three T cells can be seen: one is not interacting with any $\mathrm{MHCll}+$ cell (white arrow), while the other two are in close contact with $\mathrm{MHCll+}$ cells (white arrowheads). The middle and lower panels show higher magnification of T lymphocytes interacting with APCs. c) Percentage of CD4+ $T$ cells and CD8+ T cells interacting with APCs in the CP of control and progressive MS patients, defined as the T cells located directly adjacent to $\mathrm{MHCll}+$ cells (Wilcoxon rank sum test with continuity correction). Scale bar is $10 \mu \mathrm{m}$. Figure S3. Most granulocytes in the CP are neutrophils. Representative images of one CP section immunolabeled with CD66b (red) and elastase (green). Maximum projection image. White arrowheads point to CD66b + elastase+ neutrophils. Scale bars are $50 \mu \mathrm{m}$. Figure S4. PCA plot of the samples used in this study, showing standardized principal components 1 and 2. Axes show the percentage of variance explained by each principal component. Variables included in the analysis: density of CP MHCII+ macrophages, MHCIl- macrophages, DCs, total T cells, CD4+ and CD8+ T cells, percentage of T cells interacting with MHCll+ cells, B or plasma cells and granulocytes. PC: principal component; PMS: progressive MS. Figure S5. PPMS and SPMS patients present similar non-circulating (stromal and epithelium-associated) immune cell subsets in the CP. a) Density of non-circulating CD3+ T cells in PPMS and SPMS patients (Welch Two Sample t-test). b) Ratio of non-circulating CD4+ vs CD8+ T cells in PPMS and SPMS patients (Welch Two Sample ttest). c) Density of non-circulating MHCII+ macrophages in PPMS and SPMS patients (Welch Two Sample t-test). d) Density of non-circulating MHCII- macrophages in PPMS and SPMS patients (Welch Two Sample ttest). d) Density of non-circulating Iba1-MHCII+ DCs in PPMS and SPMS patients (Wilcoxon rank sum test). e) Density of non-circulating granulocytes in PPMS and SPMS patients (Wilcoxon rank sum test). PPMS: Primary Progressive MS; SPMS: Secondary Progressive MS 
Additional file 3: Movie 1. Example of a T cell (CD3+, green) adjacent to an APC (MHCII+, red) in the CP. Nuclei are in blue and vessels are marked with UEA I in white.

\section{Abbreviations}

BBB: Blood brain barrier; BCSFB: Blood-cerebrospinal fluid barrier; BSA: Bovine serum albumin; CNS: Central nervous system; CP: Choroid plexus; CSF: Cerebrospinal fluid; DC: Dendritic cell; EAE: Experimental Autoimmune Encephalomyelitis; MS: Multiple sclerosis; PBS: Phosphate buffered saline; PCA: Principal component analysis; PPMS: Primary progressive multiple sclerosis; RRMS: Relapsing-remitting multiple sclerosis; SPMS: Secondary progressive multiple sclerosis

\section{Acknowledgements}

Expert technical support by the Microscopy and Cytometry Core Facility in $\mathrm{O} 2$ building at Amsterdam UMC location VUmc was highly appreciated. We want to thank Evelien Timmermans for allowing us to use their microtome.

\section{Authors' contributions}

SRL, JVH, MW, GK and HEV conceived the study. SRL and JK performed most of the experiments and data analysis. SvdP helped with the experiments, and AK contributed to the optimization of experiments and image analysis. JvH and MW supervised the experiments. SRL, MW, SA and JvH selected the patient cohort. SRL wrote the manuscript with the help of JK. MW, GK and HdV revised the manuscript. All authors have read and approved the manuscript.

\section{Funding}

This project has been funded by the EU Horizon 2020 MSCA-ITN-2015 675619 BtRAIN as well as the Dutch MS Research Foundation grant (14878MS to GK).

\section{Availability of data and materials}

The datasets used and/or analyzed during the current study are available from the corresponding author on reasonable request.

\section{Ethics approval and consent to participate}

Tissue samples and associated clinical and neuropathological data were supplied by the Netherlands Brain Bank and the Multiple Sclerosis Society Tissue Bank, funded by the Multiple Sclerosis Society of Great Britain and Northern Ireland, registered charity 207495. All patients and controls, or their next of kin, had given informed consent for autopsy and use of their brain tissue for research purposes.

\section{Consent for publication}

Not applicable.

\section{Competing interests}

The authors declare that they have no competing interests.

\section{Author details}

'Department of Molecular Cell Biology and Immunology, MS Center Amsterdam, Amsterdam Neuroscience, AmsterdamUMC, Vrije Universiteit Amsterdam, De Boelelaan, 1117 Amsterdam, The Netherlands. ${ }^{2}$ Department of Pathology, MS center Amsterdam, Amsterdam UMC, Vrije Universiteit Amsterdam, Amsterdam, The Netherlands. ${ }^{3}$ Centre for Neuroscience and Trauma, Blizard Institute, Barts and the London School of Medicine and Dentistry, Queen Mary University of London, London, UK. ${ }^{4}$ Medical Biochemistry, Amsterdam Cardiovascular Sciences, Amsterdam UMC, University of Amsterdam, Meibergdreef 9, Amsterdam 1105, AZ, The Netherlands.

Received: 6 December 2019 Accepted: 24 January 2020 Published online: 03 February 2020

\section{References}

1. Abràmoff MD, Magalhães PJ, Ram SJ (2004) Image processing with ImageJ. Biophotonics Int 11:36-42

2. Aube B, Levesque SA, Pare A, Chamma E, Kebir H, Gorina R, Lecuyer MA, Alvarez Jl, De Koninck Y, Engelhardt B, Prat A, Cote D, Lacroix S (2014) Neutrophils mediate blood-spinal cord barrier disruption in demyelinating neuroinflammatory diseases. J Immunol 193:2438-2454. https://doi.org/10. 4049/jimmunol.1400401

3. Booss J, Esiri MM, Tourtellotte WW, Mason DY (1983) Immunohistological analysis of T lymphocyte subsets in the central nervous system in chronic progressive multiple sclerosis. J Neurol Sci 62:219-232. https://doi.org/10.1016/0022-510x(83)90201-0

4. Carrithers MD, Visintin I, Viret C, Janeway CS Jr (2002) Role of genetic background in P selectin-dependent immune surveillance of the central nervous system. J Neuroimmunol 129:51-57. https://doi.org/10.1016/s01655728(02)00172-8

5. Cepok S, Jacobsen M, Schock S, Omer B, Jaekel S, Boddeker I, Oertel WH, Sommer N, Hemmer B (2001) Patterns of cerebrospinal fluid pathology correlate with disease progression in multiple sclerosis. Brain 124:2169-2176. https://doi.org/10.1093/brain/124.11.2169

6. Choi SR, Howell OW, Carassiti D, Magliozzi R, Gveric D, Muraro PA, Nicholas R, Roncaroli F, Reynolds R (2012) Meningeal inflammation plays a role in the pathology of primary progressive multiple sclerosis. Brain 135:2925-2937. https://doi.org/10.1093/brain/aws189

7. Cross AH, Stark JL, Lauber J, Ramsbottom MJ, Lyons JA (2006) Rituximab reduces $B$ cells and T cells in cerebrospinal fluid of multiple sclerosis patients. J Neuroimmunol 180:63-70. https://doi.org/10.1016/j.jneuroim.2006.06.029

8. del Pilar MM, Cravens PD, Winger R, Kieseier BC, Cepok S, Eagar TN, Zamvil SS, Weber MS, Frohman EM, Kleinschmidt-DeMasters BK (2009) Depletion of B lymphocytes from cerebral perivascular spaces by rituximab. Arch Neurol 66:1016-1020

9. Dutta R, Trapp BD (2014) Relapsing and progressive forms of multiple sclerosis: insights from pathology. Curr Opin Neurol 27:271-278. https://doi. org/10.1097/WCO.0000000000000094

10. Han S, Lin YC, Wu T, Salgado AD, Mexhitaj I, Wuest SC, Romm E, Ohayon J, Goldbach-Mansky R, Vanderver A, Marques A, Toro C, Williamson P, Cortese I, Bielekova B (2014) Comprehensive immunophenotyping of cerebrospinal fluid cells in patients with neuroimmunological diseases. J Immunol 192: 2551-2563. https://doi.org/10.4049/jimmunol.1302884

11. Hanly A, Petito CK (1998) HLA-DR-positive dendritic cells of the normal human choroid plexus: a potential reservoir of HIV in the central nervous system. Hum Pathol 29:88-93. https://doi.org/10.1016/s0046-8177(98)90395-1

12. Hatterer $E$, Touret M, Belin MF, Honnorat J, Nataf S (2008) Cerebrospinal fluid dendritic cells infiltrate the brain parenchyma and target the cervical lymph nodes under neuroinflammatory conditions. PLoS One 3:e3321. https://doi.org/10.1371/journal.pone.0003321

13. Hauser SL, Waubant E, Arnold DL, Vollmer T, Antel J, Fox RJ, Bar-Or A, Panzara M, Sarkar N, Agarwal S, Langer-Gould A, Smith CH, Group HT (2008) B-cell depletion with rituximab in relapsing-remitting multiple sclerosis. $\mathrm{N}$ Engl J Med 358:676-688. https://doi.org/10.1056/NEJMoa0706383

14. Jiang H, Zhang SI, Pernis B (1992) Role of CD8+ T cells in murine experimental allergic encephalomyelitis. Science 256:1213-1215. https://doi. org/10.1126/science.256.5060.1213

15. Johnson AJ, Suidan GL, McDole J, Pirko I (2007) The CD8 T cell in multiple sclerosis: suppressor cell or mediator of neuropathology? Int Rev Neurobiol 79:73-97. https://doi.org/10.1016/S0074-7742(07)79004-9

16. Kivisakk P, Mahad DJ, Callahan MK, Trebst C, Tucky B, Wei T, Wu L, Baekkevold ES, Lassmann H, Staugaitis SM, Campbell JJ, Ransohoff RM (2003) Human cerebrospinal fluid central memory CD4+ T cells: evidence for trafficking through choroid plexus and meninges via P-selectin. Proc Natl Acad Sci U S A 100:8389-8394. https://doi.org/10.1073/pnas.1433000100

17. Korin B, Ben-Shaanan TL, Schiller M, Dubovik T, Azulay-Debby H, Boshnak NT, Koren T, Rolls A (2017) High-dimensional, single-cell characterization of the brain's immune compartment. Nat Neurosci 20:1300-1309. https://doi. org/10.1038/nn.4610

18. Kostic M, Dzopalic T, Zivanovic S, Zivkovic N, Cvetanovic A, Stojanovic I, Vojinovic S, Marjanovic G, Savic V, Colic M (2014) IL-17 and glutamate excitotoxicity in the pathogenesis of multiple sclerosis. Scand J Immunol 79: 181-186. https://doi.org/10.1111/sji.12147

19. Lassmann H, Bruck W, Lucchinetti CF (2007) The immunopathology of multiple sclerosis: an overview. Brain Pathol 17:210-218. https://doi.org/10. 1111/j.1750-3639.2007.00064.x

20. Lassmann H, van Horssen J, Mahad D (2012) Progressive multiple sclerosis: pathology and pathogenesis. Nat Rev Neurol 8:647-656. https://doi.org/10. 1038/nrneurol.2012.168

21. Luchetti S, Fransen NL, van Eden CG, Ramaglia V, Mason M, Huitinga I (2018) Progressive multiple sclerosis patients show substantial lesion activity that correlates with clinical disease severity and sex: a retrospective autopsy 
cohort analysis. Acta Neuropathol 135:511-528. https://doi.org/10.1007/ s00401-018-1818-y

22. Magliozzi R, Howell O, Vora A, Serafini B, Nicholas R, Puopolo M, Reynolds R, Aloisi F (2007) Meningeal B-cell follicles in secondary progressive multiple sclerosis associate with early onset of disease and severe cortical pathology. Brain 130:1089-1104. https://doi.org/10.1093/brain/awm038

23. Reboldi A, Coisne C, Baumjohann D, Benvenuto F, Bottinelli D, Lira S, Uccelli A, Lanzavecchia A, Engelhardt B, Sallusto F (2009) C-C chemokine receptor 6-regulated entry of TH-17 cells into the CNS through the choroid plexus is required for the initiation of EAE. Nat Immunol 10:514-523. https://doi.org/ 10.1038/ni.1716

24. Reich DS, Lucchinetti CF, Calabresi PA (2018) Multiple Sclerosis. N Engl J Med 378:169-180. https://doi.org/10.1056/NEJMra1401483

25. Sabatino JJ Jr, Probstel AK, Zamvil SS (2019) B cells in autoimmune and neurodegenerative central nervous system diseases. Nat Rev Neurosci 20: 728-745. https://doi.org/10.1038/s41583-019-0233-2

26. Serafini B, Rosicarelli B, Magliozzi R, Stigliano E, Aloisi F (2004) Detection of ectopic B-cell follicles with germinal centers in the meninges of patients with secondary progressive multiple sclerosis. Brain Pathol 14:164-174. https://doi.org/10.1111/j.1750-3639.2004.tb00049.x

27. Serot JM, Foliguet B, Bene MC, Faure GC (1997) Ultrastructural and immunohistological evidence for dendritic-like cells within human choroid plexus epithelium. Neuroreport 8:1995-1998. https://doi.org/10.1097/ 00001756-199705260-00039

28. Strominger I, Elyahu Y, Berner O, Reckhow J, Mittal K, Nemirovsky A, Monsonego A (2018) The choroid plexus functions as a niche for T-cell stimulation within the central nervous system. Front Immunol 9:1066. https://doi.org/10.3389/fimmu.2018.01066

29. Team R (2015) RStudio: integrated development for R. RStudio, Inc, Boston URL http://www.rstudio.com. 42:14

30. Team RC (2017) R: a language and environment for statistical com-puting. $R$ Foundation for Statistical Computing, Vienna

31. Tennakoon DK, Mehta RS, Ortega SB, Bhoj V, Racke MK, Karandikar NJ (2006) Therapeutic induction of regulatory, cytotoxic CD8+ T cells in multiple sclerosis. J Immunol 176:7119-7129. https://doi.org/10.4049/immunol.176.11.7119

32. Vercellino M, Votta B, Condello C, Piacentino C, Romagnolo A, Merola A, Capello E, Mancardi GL, Mutani R, Giordana MT, Cavalla P (2008) Involvement of the choroid plexus in multiple sclerosis autoimmune inflammation: a neuropathological study. J Neuroimmunol 199:133-141. https://doi.org/10.1016/j.jneuroim.2008.04.035

33. Woodberry T, Bouffler SE, Wilson AS, Buckland RL, Brustle A (2018) The emerging role of neutrophil granulocytes in multiple sclerosis. J Clin Med 7. https://doi.org/10.3390/jcm7120511

34. Zehntner SP, Brickman C, Bourbonniere L, Remington L, Caruso M, Owens T (2005) Neutrophils that infiltrate the central nervous system regulate T cell responses. J Immunol 174:5124-5131. https://doi.org/10.4049//immunol.174.8.5124

\section{Publisher's Note}

Springer Nature remains neutral with regard to jurisdictional claims in published maps and institutional affiliations.

Ready to submit your research? Choose BMC and benefit from:

- fast, convenient online submission

- thorough peer review by experienced researchers in your field

- rapid publication on acceptance

- support for research data, including large and complex data types

- gold Open Access which fosters wider collaboration and increased citations

- maximum visibility for your research: over $100 \mathrm{M}$ website views per year

At $\mathrm{BMC}$, research is always in progress.

Learn more biomedcentral.com/submissions 